\title{
足助地域における伝統的木造住宅の架構の特徵と建方

\author{
FEATURE OF STRUCTURE AND ERECTION ON TRADITIONAL \\ TIMBER HOUSE AT ASUKE AREA
}

\author{
三井真 理*, 松留 慎一郎** \\ Mari MITSUI and Shinichiro MATSUDOME
}

\begin{abstract}
In this study, we report about erection and its information of two traditional timber houses designed and built by MOMIYAMA master carpenter at ASUKE AREA. MOMIYAMA master carpenter has excellent technique and knowledge about structure design on traditional timber house.

Our target is to describe the master carpenter's knowledge of structure design on traditional timber house. Major contents of survey are drawings and specifications, TEITA, detail drawing, SHAKUZUE, process of erection, time-schedule, joint, tools, festival, and etc. On this paper we report about feature of structure and erection.
\end{abstract}

Keywords : traditional timber house, master carpenter, ASUKE AREA, erection, structure design, time-schedule.

伝統的木造住宅, 棟梁大工, 足助地域, 建方, 架構設計, 夕イムスケジュール

\section{1.はじめに}

木造軸組構法において伝統的な木造住宅の建設および 增改築は, 構造計算が行われないのは当然のこととして 設計図書さえも準備されないことが多い。そこでは，熟 練した棟梁大工が全てを取り仕切っている。一方で，木 造住宅の設計に関する棟梁大工のノウハウや知識は体得 するしかなく，また，棟梁のもっている設計上の知識を 理解するための資料も極めて少ない。本研究は, 大工養 成用の教科書や設計者のためのマニュアル作りに広く利 用出来るような架構設計に関わる基礎資料を作ることを 大きな目標としている。その目標に従って，卓越した技 能と知識を有する愛知県東加茂郡足助町在住の樅山勝己 棟梁が設計施工を行う伝統的な木造住宅の建方に着目 し, 建方調査を行うとともに架構設計に関わる詳細な記 録を作成している。本編では，そのうち，架構の特徵と 建方について分析した結果を報告している。

\section{2. 調査の概要}

棟梁が設計施工を行った足助地域の 2 階建て木造住宅 2 棟の建方に対し，調查を実施した(図 1 )。調查時期は 1994年 3 月 23 日 27 日の K 邸（写真 1 ）と同年 9 月 18 日 〜23日に実施された $\mathrm{H}$ 邸（写真 2) である。棟梁の作成 した設計図書に従い，調查用の伏図を起こした。建方前 日にヒアリングや継手仕口等の記録作成を行った。建方 当日は，写真撮影と架構図調查図により建方手順と夕イ

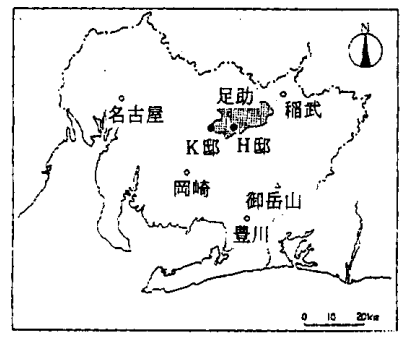

図 1 調查地
* 新潟職業能力開発短期大学校住居環境科 講師・工修

** 職業能力開発大学校建築工学科 助教授 . 工博
Lecturer, Housing Environment Department, Niigata Polytechnic College, M. Eng.

Assoc. Prof., Dept. of Architectural Engineering, The Polytechnic University, Dr. Eng. 
ムスケジュールの記録を作成した。さらに，祭礼の記録 と, 架構や職人に関するヒアリング調查を行った。調查 内容は, 設計図書, 手板, 詳細納まり図, 尺杖, 建方手 順, タイムスケジュール，部材名称，継手·仕口，道具， 職人，祭礼と，多岐にわたっている。これらの建方に関 する基本情報を補足するものとして，後日，棟梁ならび に職人に再度ヒアリング調查を行った。

棟梁は樅山勝已氏 (昭和 7 年 5 月 15 日生まれ), 調查対 象住宅は愛知県豊田市幸海町の K 邸および愛知県東加 茂郡足助町の $\mathrm{H}$ 邸の 2 棟である。調查メンバーは, $\mathrm{K}$ 邸 で6名，H 邸で4名であった。

この地域には, 現代でも伝統的な架構が随所に見られ, 日本の伝統的な間取りである整形四間取り(この地域で は「四八」という）の系譜を継承している。特に，今回 の調查対象である柇山勝己棟梁は，(1)常時技能の高い大 工を 5 名抱えており，道具の作成と手入れも行っている。 (2)木造住宅を年に数件元請けとして受注し，地域に根ざ した住宅生産を行い，木造住宅の新築工事だけでなく， 改造や改築工事等も多い。(3)年に 1 物件程度，社寺建築 も手掛ける。(4) 2 級建築士の資格を持ち自分で確認申請 用の図面を書く，(5)地域の棟梁大工たちからの人望が厚 い，など自他ともに認める足助地域の代表的な棟梁大工 であると言える。

\section{3. 言葉の定義}

本研究が扱う架構のうち, 特に特徴的な言葉である中 桁や隅梁, 地棟, 落ち屋根を以下のように定義する。
(1)「中桁」とは, 小屋組に㧈いて，梁間 (初重梁) の 中央で小屋梁を受け，柱の頭をつないでいる析行き方向 の梁を指す。これに対し，軒桁を「本桁」と呼ぶ。(2)「隅 梁」とは，小屋梁上部に本㭲間を45度でクロスに渡され る梁材のことで, 中桁と小屋梁と隅梁で三角形を構成す る。(3)「地棟」とは，4 重梁となっている和小屋組にお いて, 棟の值下 4 重梁 (六天) の上に棟木と平行に通し た桁行材のことである。足助地域では，「地棟」や「寿棟」, あるいは棟木の次に入るという意味から「次棟」の漢字 を用いている。(4)「落ち屋根」とは, 主屋屋根に対して 1 段落ちた屋根部分を指寸。

\section{4. 樅山棟梁の架構の特徵}

調查対象である $\mathrm{K}$ 邸および $\mathrm{H}$ 邸について，全体架構 四（図2，図3）を示寸。

棟梁が用いる架構の特徵としては，(1)全て真壁造りで あること, (2)通し柱が多用されていること, (3)大鴨居(差 鴨居）および胴差しが使用された指物造りであること， (4)中桁や隅梁，地棟を用いた和小屋組であること，(5)軒 先をセガイ (出桁) 造りとしていること，(6)落ち屋根と していること, 等が挙げられる。

特に大きな特徴として，小屋組において中桁を 3 本使 用することや, 隅梁を何組も使用することが挙げられる。 図 2 の $\mathrm{K}$ 期の小屋組には，中桁が 3 本用いられている。 足助地域で見られる住宅の小屋組には, 中㭲は通常 1 本 用いるだけであるが, 棟梁の場合, 中桁を 3 本使用する。 図 3 の H 邸の小屋組には隅梁が用いられている。隅梁

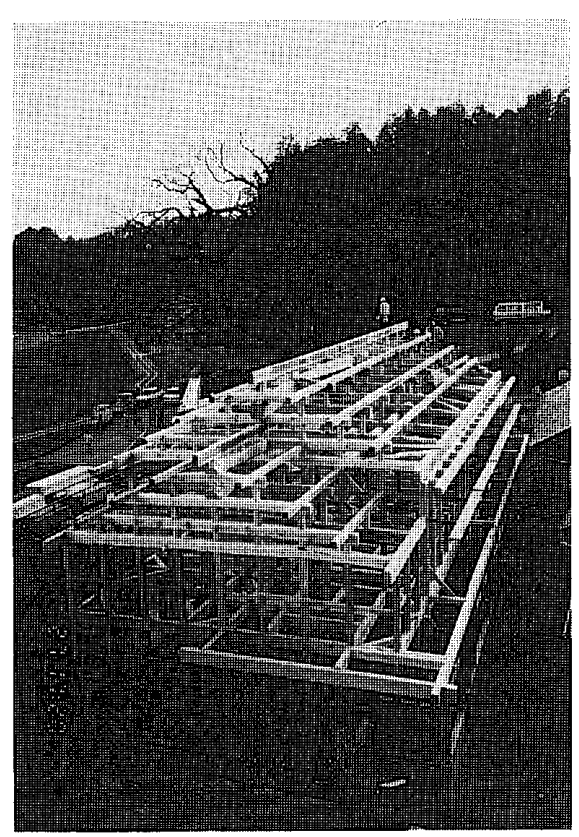

写真 1 建方終了直前の全景（K 邸）

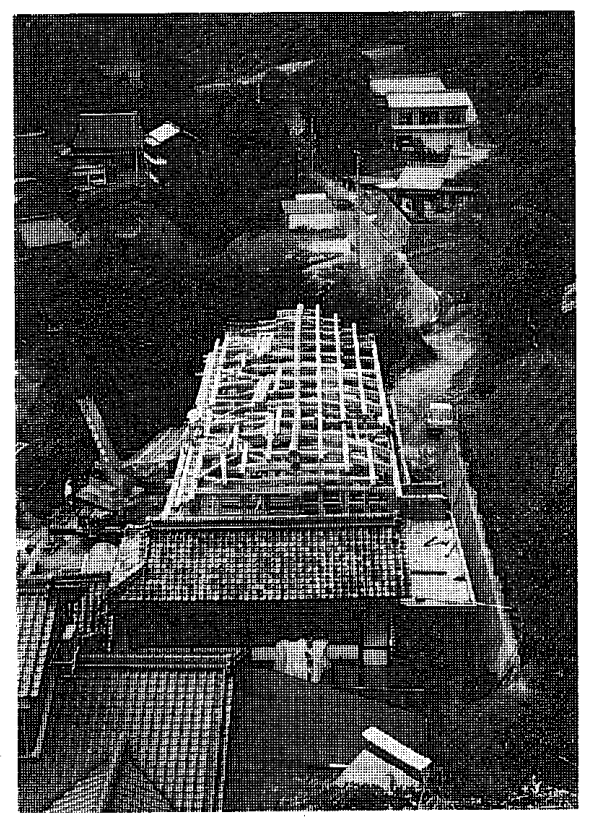

写真 2 建方終了值前の全景 (H 邸) 
は，小屋梁上部に架けられる小屋梁とほぼ同寸の水平斜 材であり足助地域特有のものとも思われるが，筑波地域 でも同様のものを見たこともあり，全国のどの地域にど の程度分布しているか明確ではない。足助地域では，隅 梁は通常両妻側の 4 隅の火打ち梁から 45 度に渡され, 中 桁上部で止められる。棟梁の場合, 隅梁を本桁間に $2 \sim 3$ 組クロスさせて配置し， 中桁と小屋梁を上から押さえる とともに, 小屋組の水平構面を固める役割を期待してい る。

また，棟梁が使用する軸組材は断面寸法が大きく，柱 は東濃の檜，桁および梁材は近郊の地松等，全て地元及 び近郊の国産材であることも特徵として指摘出来る。

\section{1 中桁}

主屋の小屋組は, 基本的には小屋梁を中桁 3 本で受け, 経済的余裕がある場合に隅梁を用いる。参考文献5)の「愛 知の民家・建築と生活」には，『中桁は，別名「平桁」と も呼ばれ，「鳥居建」民家の上屋柱間に架け渡された屋根
を受ける梁間中央の横架材である「さす受け梁」を受け る桁行方向の梁として,18世紀初期に発生した。鳥居建」 が尾張地方では「中桁造り」とも呼ばれており，足助地 域での中桁も「鳥居建」にみられる中桁が発展したもの である。との記述がみられる。

中桁は，小屋梁と 1 間の升を作る「井桁組」とするこ とで, (1)水平強度を増す, (2)架構体の横振れを止める, (3)中だるみを防ぐ，等の主として水平力に対抗し，小屋 組の水平構面の強化を図るために用いられる。建物規模 の大きい，才なわち，本屋普請の場合には，棟梁は必ず 中桁を 3 本使用している。棟梁が設計施工を行うほとん どの住宅に中桁が 3 本使用されている。

棟梁が中桁 3 本使用しているのは，20年以上前に修理 を依頼された強風地域である御岳山（新城北）禁の子守 堂の小屋組に，中桁が 3 本使用されているのを見たこと がきっかけとなっている。小屋組を，「中桁 1 本と隅梁を 2 組」とするものから，約15年前にこの「中桁 3 本」に

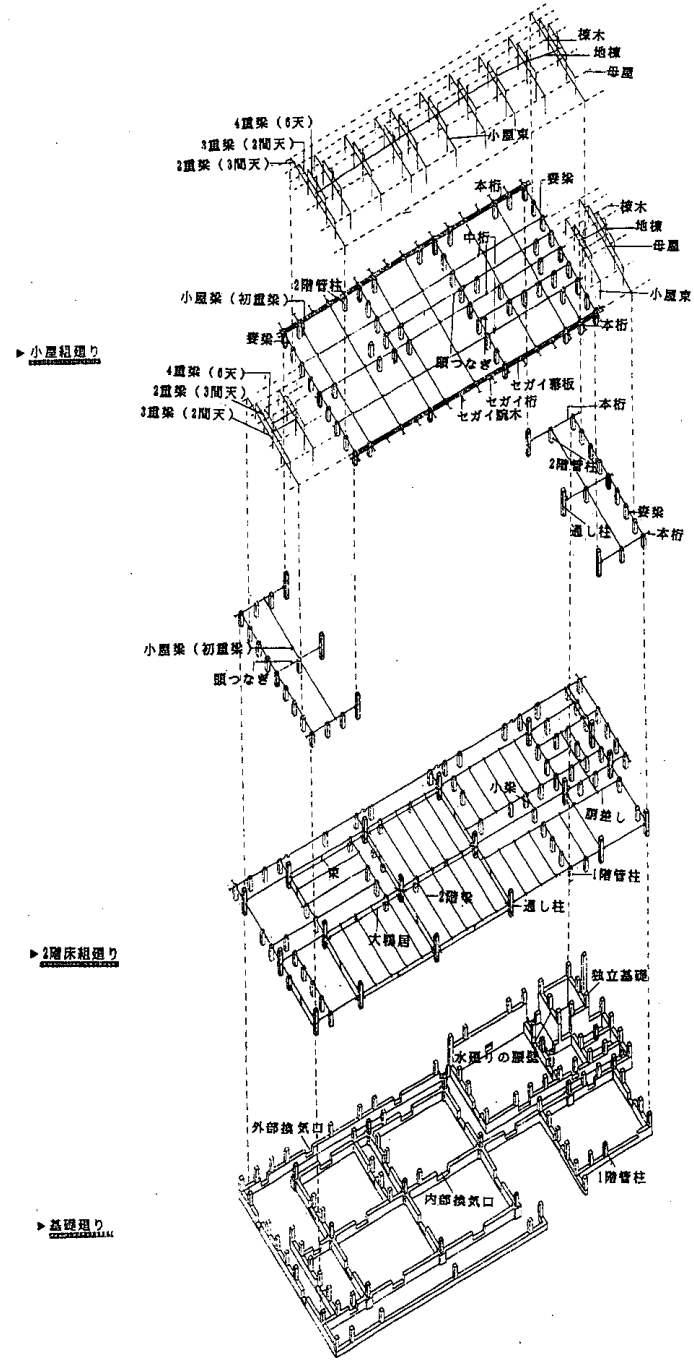

図 2 全体架構図（K 期）

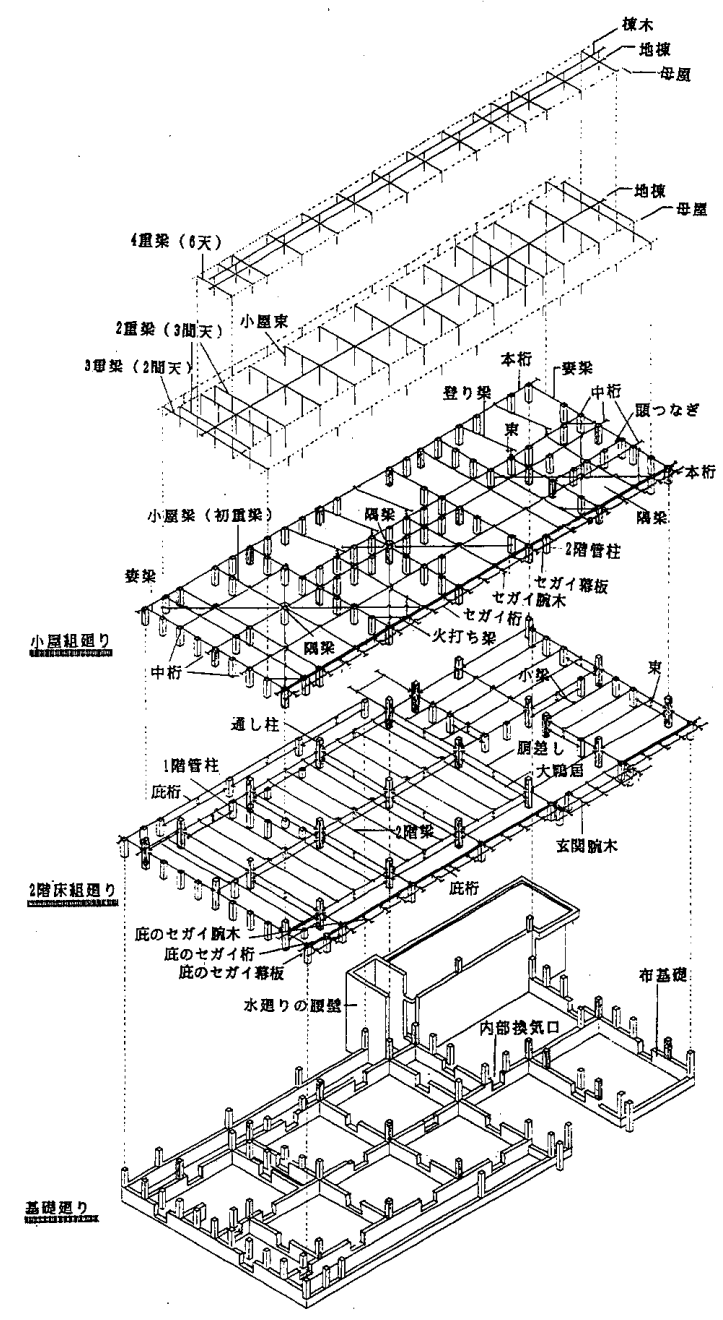

図 3 全体架構図（H 邸） 
変更している。棟梁は，「中桁 3 本」の方が構造的に強い と考えている。

\section{2 隅梁}

隅梁は，小屋梁と中桁の交差部を上から押さ之小屋組 をさらに強固なものとするために，原則として，雨妻側 4 隅の火打ち梁から 45 度に 2 組, 反対側の本桁まで配置 する。経済的に余裕がある場合には，さらにもう 1 組， あるいはそれ以上の隅梁を使用する。隅梁どうしが中桁 上で交差するように配置する。

隅梁と中桁と小屋梁で三角形を構成することで, (1)水 平強度を增す，(2)架構体の振れを止める，という特徵が でてくる。中桁 3 本同様, 小屋組における水平構面の強 化を図るために用いられる。

樅山隅梁が隅梁の技術を修得したのは，堂宮建築も手 掛けていた鬼頭親方のもとでの修業時代である。隅梁を 使い始めたのは，昭和 30 年の足助の林邸の新築工事 (平 屋）からである。梁間が 4 間の場合には，これまでは隅 梁を用いた小屋組が多かったが，最近では，「中析 3 本」 を用いるとのことである。今回の $\mathrm{H}$ 邸の小屋組では約 10 年ぶりに隅梁を使用している。棟梁が为梁を用いるのは, (1)建物が大きい，(2)小屋梁が 4 間以上である，(3)経済的 な余裕がある, (4)施主の要求による, という場合である。

小屋梁や隅梁に必要以上の大径木を用いるのは, 建物 上部から押しつけるように荷重を加えた方が建物が丈夫 になるという理由からであろう。しかし，隅梁は，火打 ち梁に架け渡されているものの本桁や妻梁とは離れてお ク，斜材としての構造的な機能が十分にあるとは考えに くい。このため, 隅梁は, 建物の捻れやゆがみを防ぐと いう意味では効果的ではあるものの, むしろ, 屋根荷重 に隅梁の荷重が増える分だけ，構造的には不利になると 思われる。棟梁は, 実際には「中桁 3 本」が最も良い小 屋組であると判断している。従って, 隅梁には, 構造的 な意味よりも, むしろ, 複雑な小屋組の木組みにおける 架構技術の披露や小屋組架構の装飾化など, 架構美を意 識した意匠的要素が強く現れていると考えられる。特に，

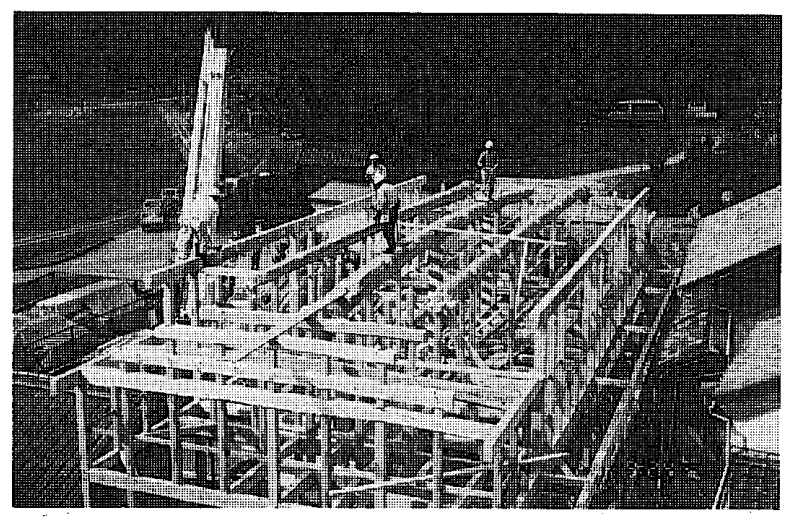

写真 3 中桁 3 本 (K 邸)
上棟式のお披露目時に，小屋組に使用する木材の多さや 架構の複雑さを見せることによって，構造美や力強さを 視覚的に印象づけることを重視している。

同時期に実施した小屋組架構に関する足助大工へのア ンケート及びヒアリング調查によると，隅梁の分布は， 足助町, 下山村, 旭町, 稲武, 豊田, 北設楽, 小原, 藤 岡, 豊橋, 名古屋東部となっている。

隅梁の起源としては，(1)洋小屋寄棟屋根の隅木部分に おける下弦材，(2)堂宮建築の隅部に使用される桔木，(3) 寄棟や入母屋の隅木，(4)隅腕木，(5)隅部の投げ掛け梁， 等が考えられるが, 確定出来ない。

また，足助地域における隅梁の発生や普及について， 地域の棟梁たちは以下のように話している。(1)足助地域 の町場大工と田舎大工の統合が図られる戦後期に発生し だ1)。(2)気候や生活環境といった風土的および立地条件 により昔の構法が改良されることなく発達してき

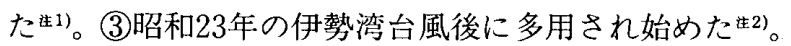

\section{5. 建方手順}

主な軸組の建方日数は，K 邸は3.5日， $\mathrm{H}$ 邸は 6 日で あった。 $\mathrm{K}$ 邸では，樅山棟梁以外に 5 人の大工と蔦 1 人 に手伝いが 1 人の総勢 8 名及びレッカー- 1 台で建方を 行った。 $\mathrm{H}$ 邸では，基本的には 7 名（1 日だけ 8 名）と レッカー1台で行った。H 邸の建方にはかなり日数を費 やしており，その理由として，以下の項目が挙げられる。 (1)狭小な敷地による制約，(2)猛暑による作業時間の減少 と作業効率の低下，(3)雨による作業の中断，(4)隅梁使用 による複雑な小屋組の架構。

建方手順の概略を図 4 に示す。架構設備にとって，建 方作業の手順を考慮することは重要な要素のひとつであ り，効率良く安全に組むことが目標となる。

通し柱, 胴差し, 大鴨居, 束で構成される「区画」部 分は，基本的な間取り，架構，住宅の形を決める重要な 架構である。この区画部分の建方手順について整理する

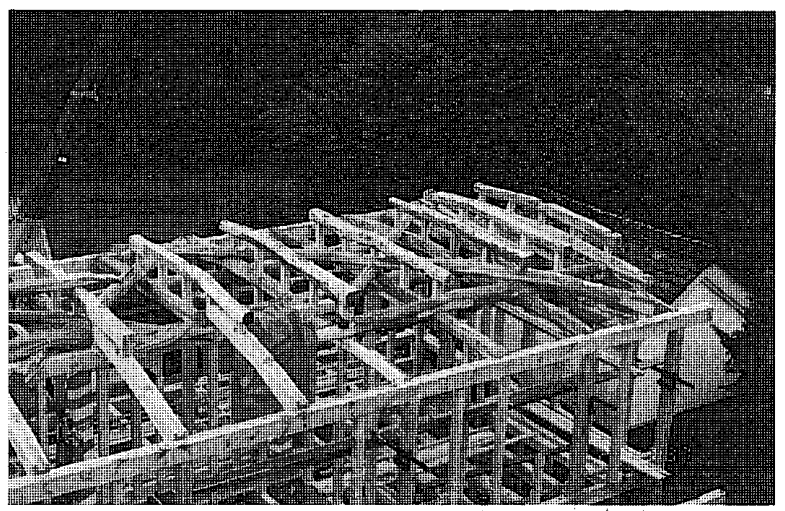

写真 4 隅梁（H 邸） 


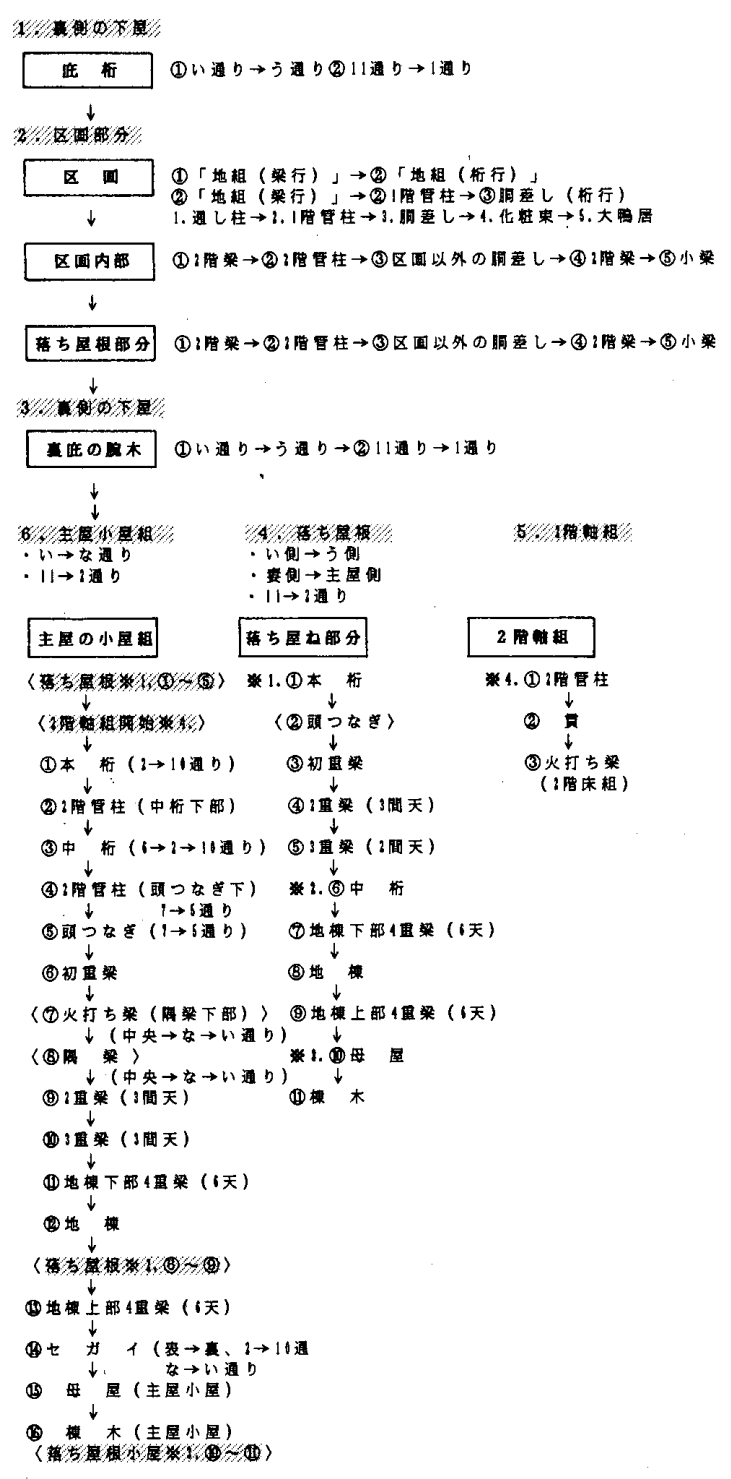

図 4 建方手順の概略
と，以下のようになる。

(1)建方は，「基本フレーム（図6）」を単位として行わ れる。基本フレームとは，通し柱 3 本と通し柱間に刺さ る胴差し 2 本，場合によっては大鴨居と束を加えた，梁 間方向の 2 スパン分を指す。(2)必要な基本フレームはあ らかじめ地組を行い，基本フレームをつなぐ同差しや大 鴨居や束と一緒に敷地内に整理して置く。(3)対面する 2 つの基本フレームを建て起こし，基本フレームの通し柱 に胴差しや大鴨居等を差し込み, Eの字形をつくる。この $\mathrm{E}$ の字形に別の基本フレームをつなぎ，梁間方向の 2 区 画分で「基本区画（図 7)」を構成する。平面的には日の 字形となる。(4)日の字形の基本区画に胴差しや大鴨居を つなき，更に，次の基本フレームを建て起こし，2つ目 の基本区画を構成して田の字形をつくる。(5)全ての基本 区画を，順次，建て起こしていく。

$\mathrm{K}$ 邸および $\mathrm{H}$ 邸の区画の建方手順を，図 8 と図 9 に示 す。K 邸における区画の建方は，(1)裏側の庇桁，(2)大黒 柱 $^{ \pm 33}$ と亭主柱进4)含む和室廻りの基本区画, (3)和室廻り

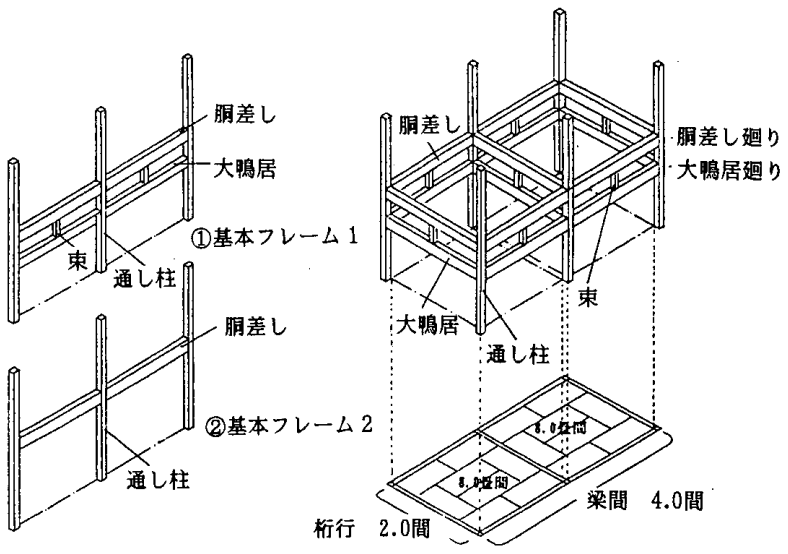

図 6 基本フレーム

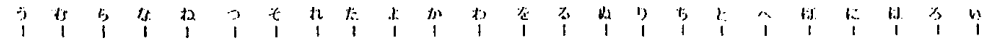
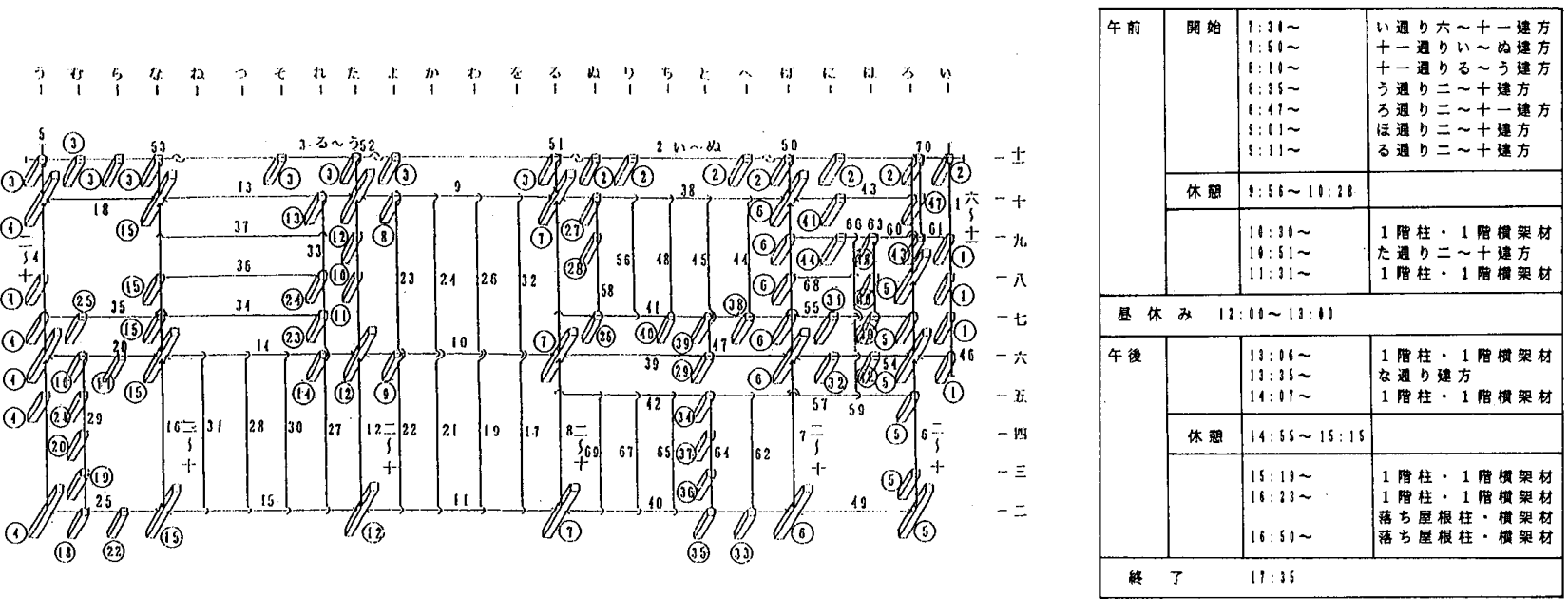

図 52 階床組における建方手順と詳細なタイムスケジュールの例（K 邸：3 日目） 
の他の基本区画, (4)玄関および LDK 部分の基本区画, の 順に行われた。これに対して，H 邸では，(1)裹側の庇桁, (2)立関および LDK 部分の基本区画, (3)和室廻り（大黒柱 と亭主柱廻り）の基本区画，(4)和室趈り（休の間・仏間 部分）の他の基本区画，の順に行われている。

$\mathrm{K}$ 邸の場合，全ての基本フレームをあらかじめ地組し て, 建方を行ないやすいように敷地内に整理してあった。 これに対して，H 期の場合，地組した部材を置いておく 余裕が敷地になかったため，基本フレームごとに地組を おこない建て起こすという工程を繰り返すことになっ た。K 邸に比べ規模がやや大きいとはいえ，区画部分の 建方が，K 邸が781分であるのに対し；H 邸は891分とか なり時間がかかっている。また，レッカーより遠い場所 である北側の下屋部分が，まず最初に建て起こされた。 さらに，区画部分の建方も，敷地に余裕がないためにレッ カ一から遠い位置から順におこなわれている。

建方に関する原則を整理すると，以下のようになる。

(1)レッカーより遠い部分から建方を開始する。

(2) 早い時期に基本区画の建方を行う。

(3) 大黒柱や亭主柱等の大きな柱を含む基本区画から 建て起こし，これに付け加える形で他の基本区画を 建て起こしていく。

(4) 基本区画の建方に際しては，あらかじめ基本フ
レームの地組を行い，敷地に整理しておく。 樅山棟梁の建方に関する一般的な原則を整理すると， 以下のようになる。

(1) レッカーより遠い部分から建方を開始する。

(2) 早い時期に基本区画部分の建方を行う。

(3) 大黒柱や亭主柱等の大きな柱を含む基本区画から 建て起こし，これに付け加える形で他の基本区画を 建て起こしていく。

(4) 基本区画の建方に際しては，あらかじめ基本フ レームの地組を行い，敷地に整理しておく。

(5)あらかじめ地組した 2 組の基本フレームを桁行方 向の胴差しや大鴨居でつないだ基本区画が，建方の 基本単位となる。

上記の原則に従うと，区画部分の建方手順は，以下の ように整理される。(1)裹側の庇桁，(2)和室廻り（大黒柱 と亭主柱の基本区画より開始)，(3)玄関および $\mathrm{LDK}^{\circ}$

ただし，建方は敷地形状や建築規模等の立地条件によ ク決まるレッカーの大きさや位置，軸組材の置き場や作 業スペース，継手仕口の形状，建方時期，作業人数，等 といった諸条件に影響を受ける。したがって，基本的に は，この原則に従って建方が行われるが，H 邸のように 事例によっては, 原則を一部変更する場合も少なくない。
(1)裹側庄析

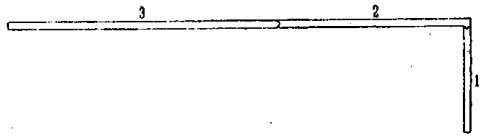

(2区画外迴り
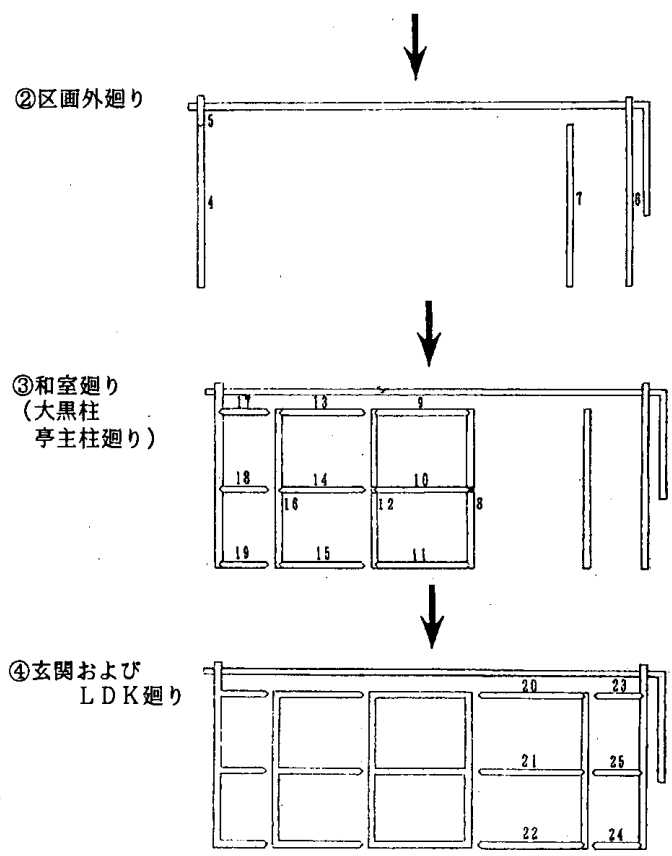

図 8
(1)裏側底标

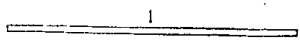

(2)玄関および L D K 迴り
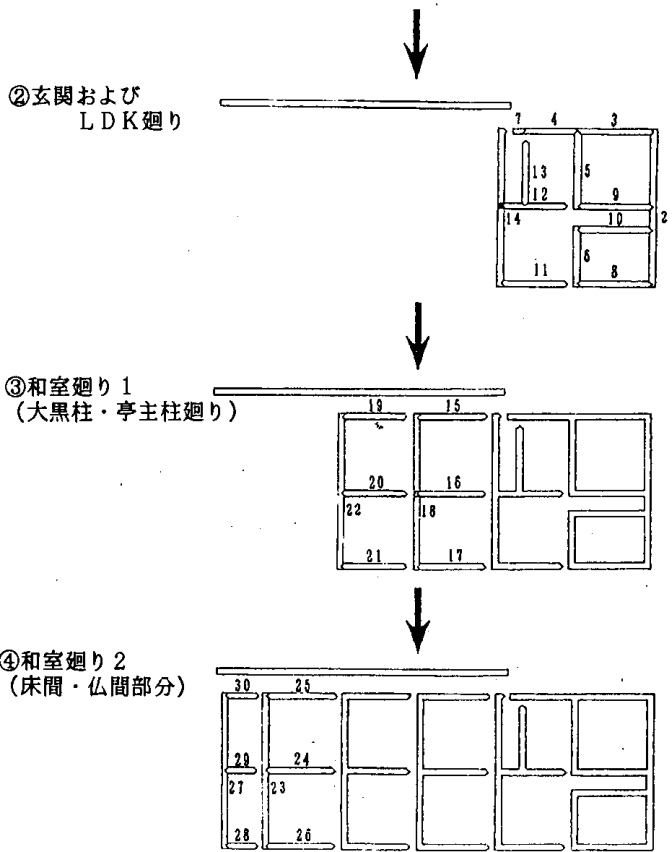

図 9 区画の建方手順（H 邸） 


\section{6. 陸前高田市における伝統的木造住宅との比較}

日本建築学会技術報告集第 2 号に揭載される「陸前高 田市における伝統的木造住宅の建方に関する調查報告」 文献17) と比較検討すると以下のことが言える。

\section{1 架構の特徵と架構設計}

玄関，続き間を中心とした和室廻り，台所や居間，2 階等の大まかな位置はほぼ同じであり，単純な矩形の平 面に対して四周にセガイが配置されていることが共通の 特徵と言える。また，真壁柱が多いこと，小屋梁が何重 にも組まれていることも共通の特徵である。

最も大きな違いのひとつとして, 通し柱と2 階の位置 が挙げられる。樅山棟梁は，通し柱を多用する。多用さ れる通し柱は大鴨居や胴差とともに区画を構成し，それ が間取りや 2 階の位置に大きく影響する。それに対して， 志田棟梁の場合には, 通し柱は, 基本的に，2 階の四隅 のみに配置される。1階に対する 2 階の位置と通し柱の 位置を決めることが, 架構設計の重要な部分となってい る。樅山棟梁に比べると, 現代の普通の木造住宅に近い とも言之る。

樅山棟梁が大きな断面寸法の軸組材を使用するのに対 して，志田棟梁は 2 階床組や 1 階小屋組に見られるよう に複数の横架材を縦横に組む。このことも，両者の違い のひとつであるとともに，現代の普通の木造住宅では見 られない特徵ともなっている。

さらに，志田棟梁におけるすみごうり，樅山棟梁にお ける 3 本の中桁や隅梁, および, それらの架構設計は, それぞれ，現代の普通の木造住宅に見られない特徴と なっている。

\section{2 建方手順}

土台から始まり，1 階軸組，2 階床組，2 階軸組，小
屋組という順に下から上へと向かって行われこと，基本 的にはレッカーより遠い位置から建方を始めること，継 手仕口に準じた木組，例えば，女木から男木の順に行う こと等は，共通の原則となっている。建方手順の差異を 整理すると以下のようになる。

志田棟梁の場合には，基本的には，地組を行わず，管 柱や通し柱を 1 本ずつ建て起こしている。すなわち，ま ず管柱を一斉に建て起こし，外周部の桁や梁を組み，さ らに，四隅をすみごうりで固定する。その後，内側の桁 や梁，あるいは，2 階部分の胴差や通し柱を建て起こし ながら組む。大きくは，外側から内側へという建方手順 となっている。

それに対して，從山棟梁の建方には，(1)基本フレーム を地組する，(2)区画部分を先に行う，(3)大きな柱を含む 基本区画から建て起こしこれに他の基本区画を付け加え てゆく，という特徴が見られる。

建方時間に関しては, 架構, 部材数, 材積, 継手仕口, および，建方に関する基本原則など，異なる点が多いた めに比較することが難しい。

\section{7.おわりに}

建方調查とヒアリング調査をもとに分析を進め，樅山 棟梁の架構設計について詳細な記録を作成した。本論で は, 特に, 架構の特徵と建方について記述している。そ こでは，長年培われてきた知恵や経験に裏付けられた架 構設計がなされている。

技能の本質を理解するには，材種，材令，調達の方法, 製材, 使用方法, 乾燥状態, 加工に要した期間, 養生等 を総合的に理解する必要があるが，本論では，架構設計

表 1 架構の特徵と建方に関する比較

\begin{tabular}{|c|c|c|c|c|}
\hline & & 足助 & 陸前高田 & 一般生5) \\
\hline \multirow{3}{*}{$\begin{array}{l}\text { 軸組 } \\
\text { 架構 }\end{array}$} & 柱 & $\begin{array}{l}\text { ·通し柱の多用（約20本） } \\
\text { ・全てが真壁柱 }\end{array}$ & $\begin{array}{l}\text { - } 2 \text { 階要所に通し柱を配置(約 } 4 \text { 本) } \\
\text { - 外壁の小壁部分と和室が真壁柱 }\end{array}$ & $\begin{array}{l}\text { - 同左 } \\
\text { ・和室のみ真壁柱 }\end{array}$ \\
\hline & 横架材 & $\begin{array}{c}\text { ・胴差しや大鴨居の多用 } \\
-ー ー ~\end{array}$ & $\begin{array}{l}\text { ·登せ梁の使用 } \\
\text { ・複層に重なる横架材 } \\
\quad \text { (仕切桁、仕切梁、敷桁、敷梁） }\end{array}$ & $\begin{array}{l}--- \\
---\end{array}$ \\
\hline & その他 & $\begin{array}{l}\text { - 区画(通し柱 +胴差し +大鴨居)に } \\
\text { より、架構の基本形を構成 } \\
\text { • 火打ち梁 }\end{array}$ & $\begin{array}{l}\text { ・すみごうり } \\
\text { (隅鼻鴨居、鼻鴨居、火打ち梁) }\end{array}$ & - 火打ち梁 \\
\hline \multicolumn{2}{|c|}{ 小屋組架構 } & $\begin{array}{l}\text { - 中桁 ( } 1 \text { 本あるいは } 3 \text { 本) } \\
\text { - 隅梁 } \\
\text { - 地棟 } \\
\text { - 小屋梁、 } 2 \text { 重梁、 } 3 \text { 重梁、 } 4 \text { 重梁 } \\
\text { (初重梁、 } 2 \text { 間天、 } 3 \text { 間天、 } 6 \text { 天) }\end{array}$ & $\begin{array}{c}-1-- \\
- \text { 敷梁、小屋梁、 } 2 \text { 重梁、3 重梁、 } \\
4 \text { 重梁 }\end{array}$ & $\begin{array}{l}--- \\
--- \\
--- \\
---\end{array}$ \\
\hline \multicolumn{2}{|c|}{ その他の架構 } & $\begin{array}{l}\text { ・セガイ造り（出桁造り） } \\
\text { ・落ち屋根 }\end{array}$ & ・セガイ造り（出桁造り） & $\begin{array}{l}--\infty \\
-\cdots\end{array}$ \\
\hline 地 & 組 & ・ 予め全ての基本フレームを地組 & ・小屋組のみを地組 & $\begin{array}{l}\text { ・架構単位こととに地組 } \\
\text { することむある }\end{array}$ \\
\hline \multicolumn{2}{|c|}{ 建方手順 } & - 基本区画部分から先に建てる & ・外側から内側に建てる & $\begin{array}{l}\text { - 各部材両端の接合部形状 } \\
\text { と位置関及ひ係柱に } \\
\text { より決定される }\end{array}$ \\
\hline
\end{tabular}


に関係する部分についてのみ調査分析を行っている。 また，その架構設計に関する卓越した知識を更に詳し く記述し，架構設計ルールとして第 3 者にも理解できる ようにすることが重要であると考える。

\section{謝辞}

調査実施に際し，從山勝己棟梁，山田将久氏，施主の 畔唖弘司氏および本藤鉦一氏には，多大な御協力をいた だいた。調查員の浜崎峰志氏，田中暁氏，金子栄憲氏， 児玉忍氏，早川光生氏の卒論生には，調查からまとめま で精力的なお手伝いをしていただいた。ここに，深く感 謝したい。なお, 本調查は, 惧住宅総合研究財団の研究 補助を受けて実施された。

\section{参考文献}

1）渋谷五郎，長尾勝馬：「新版 日本建築」，學藝出版，pp.55 $\sim 58,92,96 \sim 98,1962$ 年

2)「建築大辞典」, 彰国社, 1976年 3 月

3）長尾勝馬：「図解木造建築の知恵」, 理工図書, pp.438 $440,465 \sim 467,473 \sim 476,486 \sim 490,517 \sim 526$, 1978年.

4）川島宙次：「滅びゆく民家間取り・構造・内部」, 主婦と生 活, pp.11 147，1973年11月

5）愛知県建築士会民家調查特別委員会：「愛知の民家・建築 と生活」, 愛知県建築士会編, pp.217 229，1984年 4 月

6）田所博昭：「MAMIMU・MEMO NO. 1 閑中玩〈木造建築 覚書〉」,pp.26 72，1985年 3 月

7）日本建築学会：「構造用教材」，丸善，1985年 4 月，pp.18～ 35

8）神山幸弘，肱黒弘三，小林謙二，嘉納成男，山本順生，中 島正夫：「軸組構法による木造住宅の生産的研究」，(財新住 宅普及会住宅建築研究所報, 1985年

9）松留慎一郎, 坂本 功，大橋好光，小泉雅生：「木造軸組の 架構ルールに関する調查研究 その 1 その 4 」, 日本建築
学会関東支部研究報告集, pp. 89 104,.1986年

10）平沢岳人：「木造軸組構法の架構ルールの研究」, 東京大学 卒業論文，1987年

11）「棟梁に学ぶ家」グループ：「図解木造伝統構法 基本と実 戦」, 彰国社, pp.199 221，1989年

12）飯塚睦樹，茶谷正洋，八木幸二，山畑信博：「木造在来軸組 構法における建方手順の合理化に関する研究」, 日本建築学 会学術講演梗概集 $\mathrm{E}, \mathrm{pp} .881 \sim 882 ， 1992$ 年 8 月

13）「日本民家語彙集解」，日外アソシエーツ，1993年 9 月

14）和田裕：「甲府盆地東部の民家の架構と建方の変遷」, 東京 工業大学修士論文, pp.58 80，1994年

15）八木幸二, 松留慎一郎, 山畑信博：「木造住宅架構法研究会 の活動報告-1993年 6 月 1994年12月-」, 住宅総合研究財 団研究年報 No.21, pp.505 511，1994年

16）三井真理,松留慎一郎：「伝統的木造住宅の架構設計に関寸 る調查研究一足助地域における事例分析」, 日本建築学会学 術講演梗概集 $\mathrm{E}-1, \mathrm{pp} .573 \sim 574 ， 1995$ 年 8 月

17）松留慎一郎; 三井真理：「陸前高田市における伝統的木造住 宅の建方に関する調查報告」, 日本建築学会技術報告集第 2 号, pp.155 160，1996年 3 月

18）飯塚晆樹, 茶谷正洋, 八木幸二, 山畑信博：「木造在来軸組 構法における建方手順の合理化に関する研究」, 日本建築学 会学術講演梗概集，pp. $881 \sim 882 ， 1992$ 年 8 月

注

1）山田将久氏の話による：現在,「愛知県立障害者職業能力開 発促進校建築製図科」の講師で足助在住であるが，かつて， 樅山棟梁のもとで修業し一人前になったのち，現職に就い ている。

2）梶久雄氏と安藤源一氏の話による：足助町在住の大工棟梁

3）田の字形に配置された和室廻りの通し柱のうち，玄関側 3 本の中央の通し柱を, 大黒柱と呼ぶ。

4）田の字形に配置された和室廻りの通し柱のうち，中央にあ る通し柱を，亭主柱と呼ぶ。

5）金融公庫仕様書と参考文献18）を参照して作成した。

（1995年 8 月23日原稿受理，1996年 5 月10日採用決定） 